\title{
Lars Mjøset \\ 6 Old and New Social Movements in the Nordic Countries: History and Future in an International Perspective
}

\subsection{Introduction}

Two broad processes have interacted to create the institutional complementarities that are celebrated as key features of the Nordic models. ${ }^{1}$ We label them international integration and social mobilization. The five Nordic countries have been integrated into the Western core of the world economy under shifting great power hegemonies. At the domestic level, the mobilization of religious, farmers', workers' and women's movements have interacted with and influenced elite strategies, creating robust democracies and generous welfare states.

Today, these movements have fostered their own elites and influence routine politics in the Nordic economic area. At the same time, the Western core of the world economy, under US hegemonic leadership, faces major challenges due to uneven developments. A group of emerging economies in non-Western regions have become strong in economic terms (Amsden, 2004), with China as the largest and fastest growing. Despite the relative success of the Nordic countries, their present elites have been challenged by new social movements that address issues related to these uneven developments.

What are the chances that these new social movements will be as successful as the older ones in sustaining and revising institutional complementarities so that the Nordic models continue to both develop democracy and to remain successful in a world economy marked by the relative decline of the West? This is the question we seek to answer.

Present challenges result from three international crises. The climate issue is a truly global one, in the sense that it concerns the conditions for human survival on Planet Earth. The other two crises have occurred during a period through which capitalism has acquired more global reach. They affect the Nordic countries, however, as specifically European, EU-related crises in the areas of finance and migration flows.

1 This chapter reproduces parts of an analysis published in Norwegian (Mjøset, 2016a). I thank Knut Kjeldstadli for many interesting discussions after he launched the idea of studying the relationship between social movements and the Nordic models. 
Each crisis is addressed by a social movement: the anti-globalization, the anti-waste/environmental movement and the anti-immigration movements. We analyze these three new movements in the Nordic area, comparing them with the older movements. They are all regarded as cases of social movements that organize to influence organizational patterns, rules and routines. As such, we compare the women's movement (section 6), the most recent of the old ones, with all three new ones (sections 10-12) using the same list of properties.

We utilize one conceptual framework for each of the two broad processes. We relate international integration to hegemonic shifts (section 2) and social mobilization to political contention (section 3).

\subsection{Hegemonic Shifts in the Modern World Economy}

Table 6.1 provides a stylized model of hegemonic shifts (Mjøset, 1990; Arrighi, 1994). It allows us to situate the Nordic countries in the broader context of world economic developments since the Industrial Revolution. The two dominant great powers in the world economy have been Great Britain and the United States. Macro-historical analysis of their respective experiences as hegemonies shows that both pass through a three-phase sequence. In the first period (regulated internationalism in Table 6.1), the hegemonic state is superior with respect to all the three main sources of dominance: real economic, financial and military power (see also Table 6.2 below). This constellation borders on a world state in which the hegemon is the workshop of the world, its financial system is the world's central bank, and its military forces are the world's police-force. Superior wealth allows the hegemonic country to generously support its various allies. This applies at least to the core regions of the world economy.

In the second phase (globalization in Table 6.1), hegemony is under pressure as unequal economic development challenges the real economic superiority of the hegemon, which will use its remaining financial and military power to further its own more exclusive interests. In this period, emerging great powers catch up with the hegemon. This equalization of real economic power reduces the international capacity for 'world state' policy-making. There is no hegemonic power with the generosity to solve the tensions between older great powers and younger emerging economies. In the case of British hegemony, this led into the third phase, a long period of fragmentation from 1914 to 1947. If we observe growing fragmentation today, we have only that one case to compare with.

This framework is an ideal type that invites detailed, historically sensitive comparisons across the periods defined. It must not be interpreted as a determinist cyclical philosophy of history.

Under British hegemony, the world economic core was first North-Western Europe. In the first globalization period (1870s-1914), the US and Germany caught up with Britain within the Western Atlantic region. During British hegemony, the Nordic 


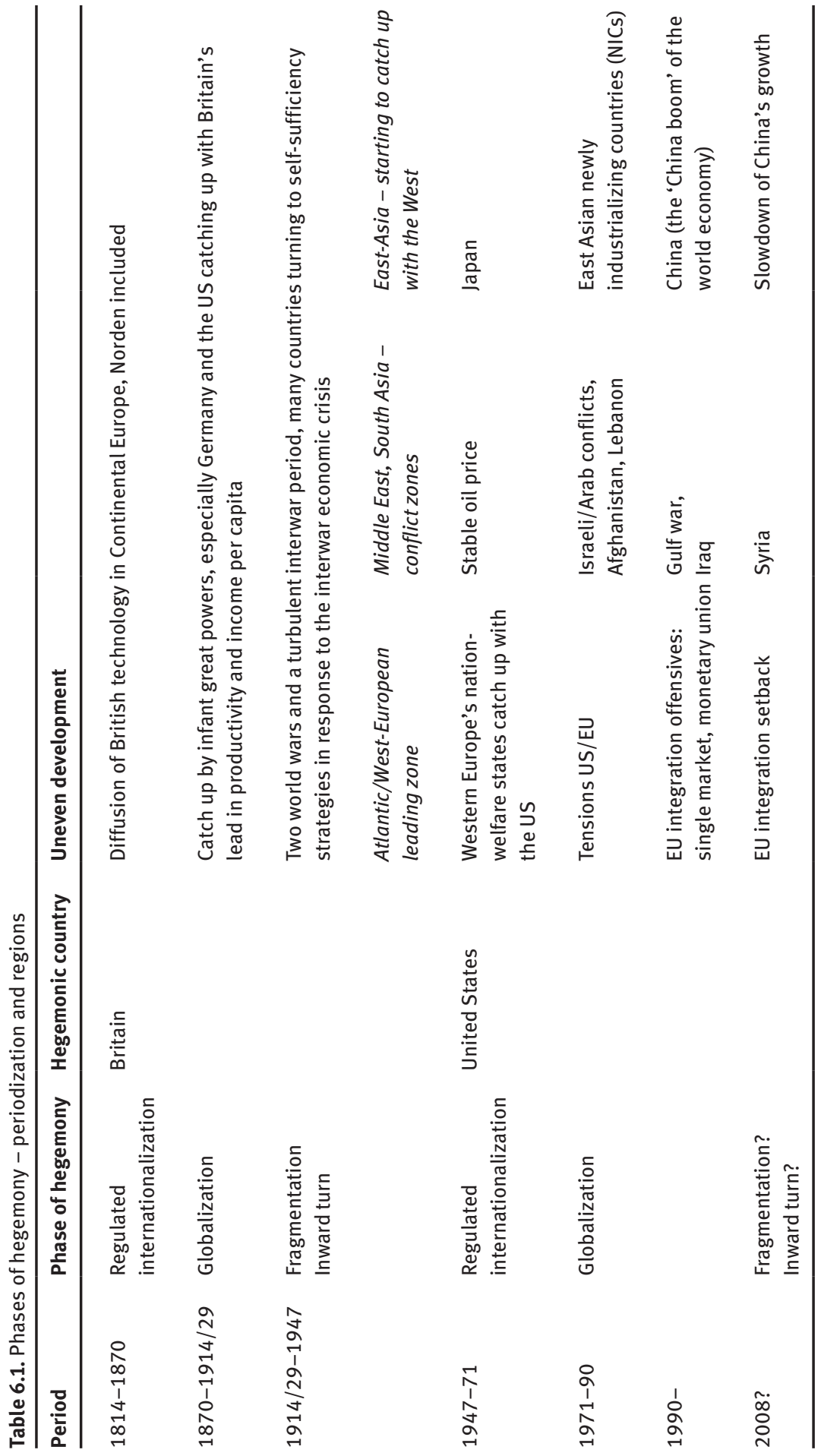


countries were integrated into the world economy. Following the fragmentation of the early $20^{\text {th }}$ century (1914-1945), US-regulated internationalism during the first Cold War decades established a highly favourable international environment for the emerging Nordic models. Both the Nordic and other Western European countries caught up with the US in the early 1970s (Maddison, 2007).

The closer we get to the present, the harder it is to observe turning points. It makes little sense to judge whether we are today still in the second period of globalization or whether the world has entered a new period of fragmentation since 2008. It is more important to compare the two periods of globalization (Table 6.1). The second period differs from the first in at least four ways.

First, the world economic growth engine has shifted out of the Atlantic/Western European area. China is replacing the US as the most important 'workshop of the world'. Second, the political system of the hegemonic country now embodies the principles of democracy (a specific variety with presidential rule, majority voting and other properties that can be specified comparatively), while in the earlier period, Great Britain was not a democracy. All the main Western-Atlantic-European great powers, the main partners of the hegemonic state (the US), combine capitalism and democracy in one way or another. Third, US hegemony has, since 1949, coexisted with an internationalist attempt at consolidating 'world state' coordination. The United Nations (UN) is a cluster of international regimes coexisting uneasily with the single hegemonic state. Fourth, the challenge of global warming is an entirely new issue on the international agenda. The productivity of modern capitalism has since the Industrial Revolution depended not only on radical technological innovation but also on fossil fuel resources (Sieferle, 1990). The severe global environmental problems of such a mode of economic growth, however, have only been known since the 1980s.

With reference to the systematic framework in Table 6.1, Table 6.2 relates these present crises to the US response to uneven developments through the most recent period of globalization - that since the 1970s.

Table 6.2. Present US exercise of hegemony, crises and new movements

\begin{tabular}{|c|c|c|c|c|}
\hline $\begin{array}{l}\text { Property of } \\
\text { hegemony }\end{array}$ & $\begin{array}{l}\text { Uneven } \\
\text { developments }\end{array}$ & $\begin{array}{l}\text { US exercise of } \\
\text { hegemony }\end{array}$ & Crisis & $\begin{array}{l}\text { New social } \\
\text { movement }\end{array}$ \\
\hline $\begin{array}{l}\text { Real economic } \\
\text { dominance }\end{array}$ & $\begin{array}{l}\text { Emerging } \\
\text { economies } \\
\text { catch up }\end{array}$ & $\begin{array}{l}\text { Weak } \\
\text { environmental } \\
\text { policies: Highest } \\
\text { per capita } \\
\text { emissions }\end{array}$ & Global warming & $\begin{array}{l}\text { Environment (anti- } \\
\text { waste) }\end{array}$ \\
\hline $\begin{array}{l}\text { Financial } \\
\text { dominance }\end{array}$ & $\begin{array}{l}\text { Financial } \\
\text { instability at } \\
\text { the core }\end{array}$ & $\begin{array}{l}\text { Mismanagement } \\
\text { of world central } \\
\text { bank function }\end{array}$ & Financial crisis & Anti-globalization \\
\hline $\begin{array}{l}\text { Military } \\
\text { dominance }\end{array}$ & $\begin{array}{l}\text { Conflict zones, } \\
\text { failed states }\end{array}$ & $\begin{array}{l}\text { Mismanagement } \\
\text { of world police role }\end{array}$ & Refugee crisis & Anti-immigration \\
\hline
\end{tabular}


Below, we first define democracy (section 3) and study its development in the Nordic area (section 4). It should be noted here that at the international level, there is no full-fledged state that can be democratized. As the model in Table 6.1 shows, international relations in the industrialized world are marked by shifts between anarchy/fragmentation and a world state surrogate in the form of dominance by one great power acting as the hegemon. We then provide a closer analysis of the emergence of the three crises after 1970 (Table 6.2): As to real economic dominance, section 7 studies uneven development in the world economy. As to financial dominance, section 8 investigates how the US has managed its role as the implicit central bank of the world economy. Finally, concerning military dominance, section 9 relates the refugee crisis to the US' policing of the world.

\subsection{Trajectories of Democratization and De-democratization}

Our framework for the analysis of social mobilization draws on Charles Tilly's analysis of democracy. In Tilly's terms (2004a, p. 8), contestation is 'politically constituted actors' making of public, collective claims on other actors, including agents of government'. In his view, democracy emerges from public contestation. McAdam, Tarrow and Tilly (2001, pp. 41ff.) devised a dynamic model of episodes of social contention. Mobilization by social movements is one among several forms of contentious politics (as opposed to routine politics), others being for example strikes, war-mongering or nationalist manifestations.

Claims are made in issue areas, areas of political and social development where economic or cultural cleavages are defined with reference to inequalities that are perceived as unjust and/or to risks that are seen as threatening. If these problems are not addressed within routine politics, collectives of actors form social movements that make public claims for change in organizational patterns, rules and routines. In this way, 'innovative collective action' results from the interaction between challenger movements and a set of (elite) state actors (McAdam, Tarrow, \& Tilly, 2001, p. 45).

A political regime is a 'set of relations between states and citizens' (Tilly, 2004a, p. 13). A regime is seen as democratizing if we find 'increases in the breath and equality of relations between governmental agents and members of the government's subject population, in binding consultation of a government's subject population with respect to governmental personnel, resources, and policy, and in protection of that population (especially minorities within it) from arbitrary action by governmental agents' (Tilly, 2004a, p. 13f.). His shortest formula is that democratization is an increase in protected consultation. High levels of such consultation count as democracy. If processes increase the level of consultation towards such a high level, the political regime is in 'democratic territory', and we have democratization. If such levels decrease, we have de-democratization. 
Tilly defines a capacity/democracy space, combining his indicators of democratization with an indicator of state capacity, understood as the ability of state agents to intervene and significantly affect citizens' resources, activities and interpersonal connections (Tilly, 2007, p. 16). Within this space he distinguishes three ideal types of state trajectories, labelled strong, medium and weak. The strong trajectory involves high state capacity relative to the level of democratization, especially in the early part of the trajectory. It may thus generate an authoritarian state or at least extended periods of de-democratization. The weak trajectory hardly arrives at democracy since early efforts are undermined by a combination of elements from three processes. First, trust networks (trading diasporas, kinship groups, religious sects, credit circles etc.) remain segregated from the regime. Second, the state reinforces the organization of society around boundaries that separate groups of people who differ collectively in their life chances (class, race, gender, caste, ethnicity, nationality, religion etc.). Third, autonomous control centres operate outside of the control of public politics and the regime's regular citizen-state interactions (Tilly, 2007, pp. 74-76).

In the medium state trajectory, each increment or decrement of state capacity is 'matched by similar change in the degree of democracy' (Tilly, 2007, p. 163). The state has already begun to build some capacity when it enters democratic territory. It has some capacity to suppress autonomous power centres. As state capacity rises simultaneously with democratization, the stakes increase, and control of the state becomes increasingly valuable for strong groups. Compared to strong state trajectories, the medium path is 'more at risk to intense domestic confrontation short of revolution' (Tilly, 2007, p. 163). De-democratization may follow from a reversal in one or more of the basic processes relating to trust networks, categorical inequalities and/or autonomous power centres (Tilly, 2007, p. 164). But if such reversals are avoided, the political regime will be marked by a combination of high state capacity and robust democracy.

The Nordic countries belong to the medium trajectory. In the following, we shall see how social movements were crucial to the emergence and development of democracy in the Nordic countries.

\subsection{Social Movements, Elites and Democracy in Norden's Development}

Since the first period of British hegemony, the Nordic countries have functioned as developmental states. They have been able to catch up, moving closer to international best practice in terms of macro-economic growth and other performance indicators. As small open economies, they have utilized leading technologies to transform their economies, upgrading resource-based exports and developing adequate manufacturing skills as well as transforming non-industrial sectors. 
One set of reasons for this development success was a historical legacy from pre-industrial Northern Europe. The prevailing family form (since at least around the year 1000) was characterized by postponed marriage, two-generation peasant households and the relatively strong status of women, despite a considerable amount of paternalism. In certain respects, the legal institutions of this agrarian society implied that women were consulted. Notably, married women were co-founders of self-reliant agricultural households, not just an element introduced into the husband's family.

Furthermore, after the $16^{\text {th }}$ century Lutheran reformation, Protestantism and Pietism had one major consequence for the broader population of Northern Europe: extensive literacy, in particular reading skills generalized at an earlier time than in other areas of Europe. A main Lutheran idea, namely, was that the congregation should read religious texts in the vernacular language. The Lutheran state church linked religious communities to the state in marked contrast to Southern Europe, where the Catholic Church remained a crucial autonomous power centre (Rokkan, 1999).

In most countries, social movements began to flourish after democracy had been established (Tilly, 2004c, p. 181). But Tilly exempts the Nordic area from this rough generalization. The Nordic countries actually had 'special purpose associations' since the mid-18 ${ }^{\text {th }}$ century (Tilly, 2004b, p. 59). The Nordic countries comprise the only regional cluster in which social movements consistently emerged before the transition to democracy (Tilly, 2004b, p. 58, using data from Collier, 1999). The first such associations in Norden emerged when the combination of high literacy rates and Lutheranism created revivalist religious movements in the region. Such so-called 'conventicles' started in the $18^{\text {th }}$ century as separate trust networks, but their main achievement was to secure the first sprouts of an independent civil society with some degree of freedom of speech and association (Nielsen, 2009). Further causes of the Nordic success can be related to the contentious politics of a series of further social movements that have challenged the routine politics of the elites.

In the wake of the religious movements, peasant movements mobilized in the early $19^{\text {th }}$ century. They secured consultation between state elites and the agrarian population. The movements pushed for novel institutions (local government legislation in Norway and Denmark) or sounded their voice within an inherited estate system where owner-occupier peasants were represented as a separate estate (Sweden and Finland). The state would bargain with representatives of local communities on major issues such as taxes and conscription of younger males into the armed forces (Mjøset \& Van Holde, 2002). While not securing full, formal democracy, the peasant movement contributed significantly to self-determination in rural areas. Trust in the state prevented the formation of regionally based autonomous power centres. In urban areas, guilds - non-state trust networks - were dismantled by state decree in the $19^{\text {th }}$ century. Given the state church institutions and 
the quite high ethnic homogeneity of the Nordic countries, cooperative institutions reproduced trust through binding consultation between state personnel and locally organized groups in civil society. In development studies, this feature - 'embedded autonomy' - has proven to be a crucial property of developmental states (Evans, 1995).

The pre-democratic social movements that we have mentioned gained concessions that represented crucial conditions for a specific combination of democracy and state capacities, which aided capitalist development. They contributed to trust in bureaucracy before the advent of formal parliamentary democracy (Shefter, 1993).

Relatively high degrees of trust, literacy and state capacity also enabled the Nordic countries to make good use of the technological impulses that were diffused from the leading economy, Britain, across the North Sea. In the $19^{\text {th }}$ century, they developed competence institutions - school systems - that reproduced the high literacy rate. The educational level improved, sustaining an increasingly skilled labour force.

Throughout the first period of globalization (Table 6.1), the development of heavy engineering industry created new layers within the elite, while international coordination capacity was weakened. The relative size of the working class grew. Class emerged as a potentially disruptive type of categorical inequality in the decades before World War I.

This challenge triggered a number of inconsistent elite strategies, confirming Tilly's expectation of intense domestic confrontation in the medium state trajectory, both before and after World War I. Some employers favoured the paternalist integration of workers at the factory level. Conservative parties wanted to meet worker contention with repressive force. Bourgeois liberal parties tried to co-opt the autonomous mobilization of workers. At the margin, the interwar period also saw fascist groupings trying to pit farmers and the lower middle classes against workers. In the same period, there were considerable efforts among activists to consolidate a separate system of working-class organizations (a 'proletarian public sphere'), potentially the start of working class trust networks that could have closed off from the state.

We have no space here to detail the separate developments in all five countries. We can only briefly summarize two main results of the confrontations before and after World War I. First, contentious politics - driven by farmers', women's and/ or workers' movements - achieved equal manhood suffrage followed by universal suffrage in the 1910s and 1920s. This consolidated democracy in the formal sense, soon to be specified as a parliamentary system with proportional representation voting rules (only Iceland lagged). Party systems - reflecting cross-cutting cleavages - evolved to become a main institution of binding consultation between state elites and the subject population. With representative parliamentary democracy, farmer and labour activists - forming their own political parties - became increasingly 
integrated in institutions that conducted routine politics while remaining closely tied to their various associations (labour unions, farmers' associations).

The second main result was the development of partnership institutions in the labour market. The interplay between an upgraded bourgeois elite and a mobilizing labour movement consolidated a structure of two, mutually opposed collective actors in the labour market: union confederations (Korpi, 1981) and corresponding employers' associations (Martin \& Swank, 2012). Between them, they established frameworks for collective bargaining (Denmark 1899, Norway 1935, Sweden 1938) (Seip, this volume).

There were revolutionary sentiments, particularly in Norway and Finland, but learning processes inside the labour movements made all the Nordic labour movements converge on a non-revolutionary, reformist line. Working class trust networks were integrated into the political regime. The labour movement would accept a government based on bourgeois parties and vice versa. We have already seen that employers followed suit in the labour market, so there was little basis for the reproduction of business elites as autonomous power centres. Sweden's late democratization can be explained by the existence in some of its regions of larger agrarian estates combined with an aristocratic upper class that held many state offices. But comparison with Germany shows that the Nordic agrarian structure, consisting mainly of smallholder family farms, made a crucial difference (Rueschemeyer, Stephens, \& Stephens, 1992, pp. 92ff.), even in Sweden.

The Labour parties entered longer-term government positions in the interwar period (Denmark and Sweden by the 1920s, Norway in 1935, Finland in 1938 and Iceland in 1939). In that period of inward orientation, state intervention and mixed economy strategies were necessary for these economies to cope, continuing adaptation and upgrading. The main elements of the Nordic models of economic and social policy-making can be discerned in that period, although strong complementarities between them evolved in the postwar period.

Since the late $19^{\text {th }}$ century, rudimentary institutions of social protection (such as accident insurance) were established as employers became aware of risks related to industrial work. Once the labour and farmers' movements learned how to operate in government offices, they influenced innovations in routine politics. In the stylized model suggested by Korpi (1983), the Labour Party used their strength of numbers to dominate parliament through red/green - worker/farmer - alliances. This development from political to social democracy particularly benefited the lower classes, workers and family farmers on small plots.

In the postwar period, during US-led regulated internationalism (Table 6.1), the national institutional complexes were strengthened under a mixed elite that included representatives of both the farmers' and the workers' movements. In a context of successful postwar reconstruction and high economic growth, universal pension systems together with increasingly well-developed health systems, became the pillars of a generous and universal service-producing welfare state, reducing 
categorical inequality, especially in terms of class. Having achieved formal democracy around World War I, these institutions deepened democracy by making substantive protection universally available as a citizens' right.

In the postwar period, the scattered arrangements were improved, consolidating social citizenship, with political rights bolstered by citizens' rights to a safetynet beyond their work income and personal savings. Those rights of course also entailed duties (taxation, conscription). As we shall see, however, in some of these welfare state institutions, women were not initially recognized on equal terms with the majority of males. This led to the mobilization that we cover in section 6. Complementary to this, the collective bargaining frameworks developed into comprehensive 'constitutions' for labour market negotiations and behaviour. This framework was mainly based on private law, with the state playing a withdrawn but facilitating role. If this was corporatism, it was nothing like the fascist 'from above' version but instead an arrangement emerging from powerful collective actors in civil society that remained the undisputed basis of a democratic political system.

All citizens were fairly equally exposed to the same public policies. Professions (such as economists and psychologists) supplied expert knowledge that increased the capacities of the state in terms of legitimate intervention into citizens' lives. Some ultra-liberal voices feared that this would cause the Nordic states to de-democratize into authoritarian regimes, but early postwar history proved them wrong.

The extension of political democracy into social democracy interacted in various ways with economic upgrading. The Nordic countries were transformed from poor, relatively backward countries into some of the most successful Western European nation-welfare states (Senghaas, 1985). The interplay between elites and movements created complementary institutional complexes that secured virtuous circles of economic development. Since the various institutional complexes (institutions of competence, cooperation and social protection) had many common features, and since experiences and plans were shared in inter-Nordic cooperative institutions, the term 'the Nordic model' is often employed (Christiansen et al., 2006).

Certainly, there were varieties of this Nordic development. Here we shall just note that Finland and Iceland deviated from the relatively convergent patterns in Denmark, Norway and Sweden. The oldest preconditions (family form, Protestantism) were similar, but their later mixed state trajectories were different. In particular, there were different processes of intense confrontation during the growth of the working class since the early $20^{\text {th }}$ century. The Finnish case was closer to a strong state trajectory, with obvious elements of de-democratization after the 1918 civil war and through the interwar period. The country barely avoided open authoritarianism, which was seen in the interwar Baltic republics. The Icelandic case was closer to Tilly's weak trajectory, with undeveloped institutions of cooperation and some quite exclusive trust networks controlling the state, weakening state capacity to address inequalities. In both cases, high levels of labour market conflict persisted into the postwar period in contrast to Denmark, Norway and Sweden. 


\subsection{Defining and Comparing Old and New Movements in Norden}

In the mid-1980s, Beck (1986) coined the dichotomy between class society and risk society, indicating two historical phases of modern industrial capitalism. The comparison of the two phases reads like a comparison between the late $19^{\text {th }}$-century labour movement and the $20^{\text {th }}$-century early postwar anti-war, anti-nuclear movements. The risks and injustices that spurred the mobilization of the labour movement affected that specific class, not (or only to a small extent) other classes. In contrast, the risks unveiled by the anti-war/anti-nuclear movement affected not just the groups mobilizing but all citizens. The dichotomy appears to indicate a general difference between old and new movements in societies that, as the Nordics did, successfully secured and maintained democracy in the $20^{\text {th }}$ century.

As we have seen, the achievement of full democracy created intense confrontation in the Nordic area during the interwar period. Successful social movements acted on the cleavages that led them to mobilize, revising and renewing routine politics, creating new organizational patterns, rules and routines. Since the end of the interwar confrontations, the Nordic area has been marked by relatively smooth transitions from contentious politics into its opposite: routine politics. We thus define old social movements in Norden as those that mobilized by establishing, securing and extending democracy, thereby reforming routine politics at the national level. Old social movements were offensive movements. Their claims could be recognized and solutions could be worked out at the national level, regardless of international conditions. They all related to democracy in one way or another. The first ones (revivalists, farmers) created important preconditions for democracy, and the later ones (workers, women) secured universal formal democratic rights and subsequently consolidated a set of social citizens' rights. This is our key conclusion concerning the impact of the old social movements on the Nordic historical path to the present.

We shall provide a more specified account of the most recent one among these offensive movements. The women's movement was already important in the mobilization for universal suffrage but gained new significance in the second period of globalization starting in the 1970s, as specified in the next section.

Returning to Beck's dichotomy, we can specify a definition of the three movements that address the three contemporary crises already discussed (Table 6.2, further specified in sections 7 to 9). As in the definition of risk society, these movements deal with risks that will affect everybody, both elites and lower strata in the social hierarchy. But that is not all. The new movements' claims address issues that root in the relations between nation states. For these reasons, the new movements are defensive ones. Their contentious politics defend national-level achievements against challenges that arise at the level of international coordination. As we have noted in section 2, in that realm there is not democracy. Rather, there is hegemony that passes through the different phases defined in Table 6.1. 
We shall specify this distinction later (Table 6.3, section 13). Here it suffices to note that we study all these social movements as cases of contentious policy-making aiming to change organizational patterns, rules and routines. We relate to five properties of social movements considered as such cases: their background; their main claims; and how they relate to three features of routine politics - expert knowledge, party politics and bureaucracy - that are crucial to processes of institutional change in states marked by combined democratization and relatively successful integration into the world economy:

1. the historical background of the movement, and the main problems addressed;

2. the main claims and arguments in favour of changing organizational structures, rules and routines;

3. the movement's relation to expert knowledge;

4. the movement's relation to political parties; and

5. the movement's relation to administrative apparatuses.

The next section uses these properties to analyze the women's movement, and in sections 10-12 we analyze the three new social movements (Table 6.2) with reference to the same list of properties.

\subsection{The Women's Movement}

(1) Historically, the active women's movement emerged as part of the mobilization for universal suffrage (Finland 1906, Norway 1913, Denmark 1915, Iceland and Sweden 1920). In the postwar 1960s and 1970s, a new women's movement directed attention to the persistence of a number of gender inequalities beyond the formal right to vote. Although postwar elites were composite ones (including organic intellectuals from farmers' and labour movements), they consisted mainly of men. The Nordic countries built a welfare state that was largely universalistic, but the supplementary pension schemes and most social policy measures were tailor-made for the male breadwinner. There was universal access to state-provided education, but men dominated in most occupations, especially those with high prestige. The share of women who passed high-level exams increased as an effect of the postwar educational revolution, but it was not always easy for them to get jobs that matched their qualifications. The new women's movement was dominated by feminism, an intellectual wave emerging in the postwar academic and literary public sphere. In the Nordic realm, feminists mobilized within a culture that was already marked by egalitarian ideals. The new women's movement served to make the formal, democratic right to vote more substantive.

(2) According to theories associated with feminism, gender inequality has its roots in patriarchal relations. An early focal point was mobilization to secure the right to selfdetermined abortion. Legislation was altered in Denmark, Norway and Sweden in the 
1970s, securing this as a right pertaining specifically to women. On other issues, the main claim was always equal rights for both sexes. This cleavage line criss-crossed class and other social divisions. It mattered in many walks of life, certainly in the workplace, but also at the domestic level, relating to what had thus far been considered 'private' matters, such as the division of domestic work (housework and care for children, the elderly and other persons in need). The feminist movement countered positions of male dominance in all relevant areas, aiming to leave women with the same degree of autonomy and self-determination as men had already achieved. The movement was rooted in the middle class, but many of its victories implied progress for women of all classes.

(3) When the labour movement first moved into positions of power - partly already in the interwar period but more thoroughly in the early postwar period - it did relate in some respects to expert knowledge. The feminist movement's reliance on expert knowledge was even stronger. The core of activists had their background in higher education, gaining influence in social science and/or in administrative positions. Within academia, feminist researchers contributed to conceptual and theoretical development. In particular, they pioneered the analysis of the rationality of caring, contributing to a large body of research literature on the varieties and effects of social policies relating to gender equality and provision for families. In Sweden, universities now have separate gender studies departments, and all Nordic countries have separate institutions that pursue research into these issue areas.

(4) With the exception of Denmark, political parties in the Nordic countries have women's sections (Bergqvist et al., 1999, p. 74). The importance of these committees increased as the new women's movement gained momentum. In the early 1970s, the percentage of female members of parliament was 21.5 in Finland, 16.8 in Denmark, 15.5 in Norway, 14 in Sweden and 5 in Iceland (Bergqvist et al., 1999, p. 298). In Iceland, the electoral system was particularly skewed in favour of men. Thus, a 'Women's list' won seats in the Althing between 1983 and 1995, the most lasting women's party in the Nordic region so far. In Sweden, a 'Feminist initiative' mobilized ahead of the 2014 election but failed to win any mps. In sum, the feminist movement has not been able establish lasting parties mobilizing with reference to the gender cleavage. It turned out that the political claims voiced by the feminist women's movement could be written into the programmes of most parties.

(5) In Finland, Norway and Sweden the women's movement formed the basis of what has been called state feminism (Hernes, 1987). Well-educated activists, often with a background in the women's sections of political parties, became leading politicians or leading administrators in the relevant ministries. Within the broader field of family policies, gender equality became a separate policy field, and several institutions were established to influence and supervise such policies. In the administrations 
of Denmark and Iceland, there was less influence by such state feminists. However, family policies still developed along similar lines.

In sum, the new women's movement gave rise to institutional reform and rules that fit into the complementarities of the Nordic models. The impact of state feminism from above converged with the persistent mobilization of the women's movement from below. Family policies, and social policies more generally, helped generalize the dual-earner/dual-carer family. Family policies granted longer parental leave, daddy quotas and improved supply of kindergartens and school activity services beyond teaching hours. Furthermore, services for the elderly (hospitals and home services) were extended. Already well developed capacities of the health system were further improved. These institutional reforms made high female labour force participation rates typical of the Nordic countries. Not just in terms of competence institutions, but also by means of social protection reforms, the Nordic countries developed a 'social investment welfare state' (Morel et al., 2012).

As family policies enable young couples to combine work and parenthood, there is little need to postpone parenthood. Thus, the total fertility rate has remained close to the reproduction rate. Forecasts of the old-age dependency ratio (the ratio of elderly people to those working) are more favourable in the Nordic area than in the rest of Europe, with some exceptions (such as France, where there is a long tradition of pronatalist family policies). In contrast to the Continental model, the Nordic model of social protection secures high labour force participation rates for both sexes. This holds true even if unemployment rates periodically may remain at a high level.

As noted in connection with Table 6.2 above, the next three sections look more closely at the second period of globalization - that since the 1970 s.

\subsection{Uneven Development after 1979 - Generalization of the Western Fossil Growth Model Creates the Risk of Global Warming}

China's recent history is a most genuine example of uneven development, affecting more than one-fifth of the world's population. China had lost all its former greatness by the early $20^{\text {th }}$ century, despite having one of the world's oldest state traditions. After the 1949 revolution, China started fossil-fuel based industrialization in the 1950s. Sino-American diplomacy in the early 1970s opened up trade and technologytransfers between China and the West. China's importance for the world economy peaked after the country was admitted into the World Trade Organization (WTO) in 2001. At present, China can celebrate a world record of economic growth over 30 years, 1980-2010, with close to double-digit average GDP growth (Mjøset \& Skarstein, 2016). There has never been anything like this catch up process. For the first time in the history of industrial capitalism, the growth engine of the world economy is located outside of the Atlantic/Western European area. 
The US and China now share a common destiny (Nordhaug \& Skarstein, 2012). The US market is crucial to China's export-oriented industrialization. The enormous US trade and payments deficits are balanced by China's large surplus, reinvested across the world. The US is now the world economy's 'consumer of last resort', combining emission-intensive luxury consumption based on a very high living standard with huge military spending and dramatic inequalities in income and wealth.

Let us compare the two periods of globalization (Table 6.1). In the first one, the US and Germany eliminated Great Britain's lead, and the European great powers clashed in two world wars. Compared to that historical experience, the East Asian catch up with the US lead since the 1970s has progressed peacefully. The model of fossil-fuel based industrialization that started with the British Industrial Revolution (Sieferle, 1990) has been generalized outside of the West - a globalization more complete than the first globalization at the end of the $19^{\text {th }}$ century.

But just at the historical point when the process of uneven industrial development attained global reach, natural scientists registered a wholly new challenge. The challenge of climate change, the risk of global warming destabilizing weather systems, became a concern for great powers and international organizations - particularly the $\mathrm{UN}$ - involved in managing uneven development.

A number of large and medium-sized countries are today emerging economies, catching up to achieve mass consumption, Western style. The basic energy source is still fossil fuels (oil, coal, natural gas). The climate crisis is the result of worldwide uneven development that generalizes the fossil fuel energy model. It applies generally that industrial society produces so much waste that it is incapable of sufficiently recycling it (Sieferle, 1990). The specific problem here is the emission of greenhouse gases (particularly $\mathrm{CO}_{2}$ ) from the burning of fossil fuels. This waste is stored in the atmosphere, causing global warming.

The UN-coordinated Intergovernmental Panel on Climate Change (IPCC) summarize the research based on climate models. The consensus result is that if the density of greenhouse gases in the atmosphere continue to rise, many climate systems may be destabilized. IPCC fears that the average temperature (compared to the pre-industrial benchmark) may be increased by more than $2^{\circ} \mathrm{C}$ around 2050 . The effects are local and differ from place to place: drought, desertification, increasing ocean-level, melting ice-cap, warmer oceans, changing ocean currents and more $\mathrm{CO}_{2}$ emissions if large permafrost areas melt and large wetland areas are converted to dry land. An extensive climate crisis still lay in the future, but it can affect all the tangible wealth accumulated by humans in specific, densely populated areas. This is the first time in human history that uneven economic development has encountered limitations that can be defined by natural science. One can hope that the IPCC is wrong, but the results are supported by a large majority of researchers, and a broad political consensus favours policy actions based on current early warnings.

The problem of climate change creates a new type of tension between emerging economies of different vintage. The atmosphere is a common, used as a dumping 
ground for greenhouse gases. But its capacity is limited. The US clearly has the highest emissions of $\mathrm{CO}_{2}$ per capita (16.8 tonnes in 2011), more than double those of the EU and China (both had 7.2 tonnes in 2011). EU emissions are decreasing, while China's emissions are on the way up. Other emerging economies are increasing their emissions from low starting points: Russia 12.6; South Africa 9.2 (same as Norway); Brazil 2.2; India 1.7; Nigeria 0.5. The oldest industrial countries have already filled more than their share, so when the Rest aims to become as rich as the West, the global greenhouse will be filled up with more $\mathrm{CO}_{2}$ than can possibly be stored without overshooting the $2^{\circ} \mathrm{C}$ target by 2050. The IPCC concludes that the major users of fossil fuels should not even exploit their remaining known deposits. The leading countries should immediately switch to a combination of non-fossil energy sources (nuclear power, solar panels, water power etc.).

In technological terms, this is possible. However, in the West both the material infrastructure and basic consumer preferences are integral parts of a social structure upheld by a high consumption of fossil energy (Geels, 2014). It does not seem that 'green' political parties (with programmes emphasizing effective climate policies) are rewarded in elections. To the average voter, the climate crisis just seems too far into the future (Brox, 2009). Furthermore, the quota trade systems implemented thus far in the wake of the Kyoto protocol (1997/2005) have not led to significant emission reductions.

International regimes and transnational actors try to influence actions at the national level. The UN participates in the IPCC and arranges climate conferences, most recently, the Paris 2015 agreement. The EU has tried to take a lead, and in 2015, there was an accord between the US and China. But in a phase of globalization marked by the weakening of hegemony, the international capacity for 'world state' policy-making is reduced. There is no hegemonic power with the capacity - and thus generosity - to solve the tensions between the oldest and the youngest emerging economies. In May 2017, the US withdrew from the Paris agreement. This is the situation that spurs social mobilization against global warming in Norden and elsewhere.

\subsection{Different Effects of Financial Instability - Internal Western Tensions between the US and the EU}

International monetary instability was the first indication of weaker US hegemony following the Western European early postwar catch up. Since the termination of the USD (dollar) gold convertibility in 1971, the US has abused its role as the world's central bank. Competitive devaluations and financial bubbles had destabilizing effects across the world, particularly so in the Western European area where the industrialized economies of the nation-welfare states were strongly interdependent.

The EU response was a series of integration offensives. Plans for a closer union were not possible to realize in the 1970s, but the Single European Act established the single market in 1991. This reduced the costs of regional trade. The second offensive was the 
Economic and Monetary Union, culminating in the monetary union based on the euro in 1999. This reduced EU vulnerability vis-à-vis fluctuations in the key currency, the USD. Both these offensives were attempts to stabilize the EU, making it less vulnerable to the self-interested US use of its privileged position in the world monetary system (Table 6.1). Both these measures implied a deepening of the union, while a third offensive widened the union to 28 member countries. Especially the inclusion of a series of former Eastern Bloc countries in 2004/2007 increased the diversity of economic development levels, triggering larger internal flows of labour power. This affected all the Nordic countries. Denmark had been an EU member since 1973, Sweden and Finland had joined in 1995, while Norway and Iceland remained non-members but were fully integrated in the EU single market through the EEA agreement (European Economic Area). Internal migration flows implied significant pressure on the institutions of social partnership, especially on the arrangements prevailing in the labour market.

In the US, investment banks successfully lobbied in favour of extensive deregulation of the financial sector. New financial instruments increased systemic risk, and short-term, speculative capital movements gained enormous proportions, with bubbles bursting in the dot.com crisis of 2000 and the subprime crisis of 2008. US monetary authorities had no capacity to pursue its financial hegemony in a responsible way.

Deepening the union had strengthened the EU's supranational features, partly counteracting trends towards weaker international coordination. But the EU remained a state system of nation-welfare states, responding to the financial crisis with a focus on its own banks. The repercussions of the financial crisis thus became particularly severe in the EU Eurozone. States chose to rescue banks that had accumulated new financial instruments and that also had financed European property and stock exchange bubbles. The banking crises were transformed into sovereign debt crises. Devaluation was excluded even in situations of major real economic instabilities. In a situation similar to the deflation years of the 1920s, the weakest EU economies (Greece, Italy, Spain, Portugal, Ireland) were most severely affected.

In contrast to the three integration offensives, this was an integration setback. The EU Eurozone was on a path of seemingly irreversible austerity due to the sovereign debt crisis triggered by the US subprime crisis. Another integration setback in 2015 is analyzed in the next section.

\subsection{Different Effects of the US Role as World Police - Conflict Zones and Refugee Flows in the EU-Connected Regional Migration System}

The main challenges to US world policing have occurred in the Middle East. Since the 1960s, US policies here became a complex balancing act between support to Israel and alliances with selected Arab OPEC members. Striving to secure a stable oil price, the US became entangled in local struggles between the regional great powers in the 
Arab Gulf: Iran, Iraq and Saudi Arabia. The US also became involved in South-Asia following the USSR invasion in Afghanistan in 1979 (Mjøset et al., 2012).

As part of these processes, groups of political Islam activists gained stronger positions, both as micro-networks pursuing terrorism and as elites in theocratic states such as Saudi Arabia and Iran. The Al-Qaeda terrorist network gained a position for itself as a geopolitical player by successfully humiliating the US in the 9/11 2001 Twin Towers attack. In response, the US started the 'War on Terror', intervening in Afghanistan in 2001 and Iraq in 2003. These attempts at regime change had wide-ranging negative unintended consequences. Vicious circles of sectarian violence in authoritarian states with complex potential ethno-religious and regional conflict lines scared masses of people into fleeing. Many of these flowed through the migration system that connects the extended Middle East and North Africa with the EU/EEA Schengen region (Massey et al., 1998). Along the escape routes, middlemen (many of them organized in criminal networks) made money on the trafficking of hapless people turned asylum-seekers.

The single market integration offensive starting in 1991 necessitated EU control of the flows of poor and unskilled people into its borderless market. The nation-welfare states were happy to accept well-educated, highly skilled immigrants, but experiences with waves of asylum-seekers escaping conflict zones led to political discontent. Decades of immigration had created large urban congregations of Muslim immigrants in several Western European cities. Parts of the native nation-welfare state citizenry became responsive to political reasoning that in various - mostly indirect - ways tried to frame Europe's population of Muslim immigrants as a serious risk factor. Right-wing populist parties discovered that they could win votes by exploiting a fear of political Islam. New policy fields - immigration control and policies of integration - gained in importance. It seemed that the less successful a country's pursuit of integration policies was, the more this new cleavage influenced the party system. That regularity applies in most, but not in all, cases. Sweden has remained exceptional for some time, but may not hold out much longer.

While the three EU integration offensives had promoted liberalized flows of trade and finance in the single market, the EU now built stronger legal and practical barriers against inflows of certain types of labour from external areas (Livi-Bacci, 2012). The Schengen agreement established external border controls (1985, 1990, 1997), and the Dublin agreement $(1990,1997,2013)$ established rules on the treatment of asylumseekers (Geddes, 2008). As for refugees, the UN administers a more global system. Furthermore, each country developed bundles of policies to integrate refugees at the national level. This institutional complex functioned quite well as long as the migration flows came in smooth cycles with no major peaks.

2011 saw an eruption of popular mobilization against the Middle Eastern militaryauthoritarian regimes. The most serious long-term effect was the civil war in Syria. The tragic situation reflects a failure of international coordination between the major great powers (US, EU and Russia). It has worsened by the cynical involvement of regional great powers (Turkey, Saudi-Arabia, Iran) interacting with a neighbouring 
failed state (Iraq) and a weak, fragmented Syrian opposition. A major unintended consequence of the US invasion in Iraq was the strengthening of militant 'holy warriors' in the destabilized areas of Iraq and later in Syria, too. Taking over from Al-Qaeda, the self-proclaimed 'Islamic State' (IS) in 2014 gained territorial power in the Iraq/Syria borderland. This was the first time in recent history that a terror organization has proven able to permanently control a larger territory. Like Al-Qaeda earlier, IS positioned itself as a geopolitical player.

Both in the US and in Europe, these developments influenced threat perceptions. Small groups among second-generation immigrants - sensing marginalization, or even just a lack of recognition - discovered political Islam and went through a process of radicalization, joining extremist groups such as IS (Nesser, 2015). Especially European countries came to experience the problem of 'foreign warriors' recruited to fight in the Middle East, especially with IS in Syria and Iraq. Panics concerning terrorism has been exacerbated by violent actions on Western territory, such as in Paris and Brussels in 2016 and London and Manchester in the spring of 2017. Most of these actions were carried out by young men that had grown up in Europe.

In 2012, people started to escape from Syria. In 2015, the tragic vicious circles produced a wave - the 'refugee crisis' - of refugees through the Middle East/EU migration system. In addition to Syrians, the wave consisted of asylum-seekers from Afghanistan and Iraq (clearly related to US policies in the region) as well as from conflict zones (e.g. Eritrea) with more peculiar problems and without any strong connection to US-Middle Eastern politics.

The refugee crisis is the result of weakened international coordination capacity. Most commentators agree that the US exercise of military power has gone very wrong. Destabilization, with more and even deeper conflict zones in the Middle East, fuels migration flows into the EU. The US is not strongly linked to that migration system. The US has its own migration system with South and Central America (Massey et al., 1998). Even there, one finds conflict zones (such as Columbia), but the shares of pure labour migrants are higher than into the EU. Furthermore, the US is one unitary great power, while the EU must strive to manage the conflicts that immigration from conflict zones generate between its many welfare state members. Finally, migrants into the US are mostly Catholics, a religion with nothing that resembles the shia/sunni divide or political Islam. Compared to the US system, the regional migration system into the EU creates more serious problems.

Open routes into Europe in the fall of 2015 led to particularly large flows of asylum-seekers into the Schengen area. Germany and Sweden were regarded as the most immigration-friendly countries, attracting the largest shares of asylum-seekers. Southern EU countries of first arrival stopped storing fingerprints, just letting the flow of immigrants pass through to destinations further north. After a few months of such free flows, the nation-welfare states took action. EU countries north of the Mediterranean reintroduced border-controls inside of the single market. By late 2015, the Schengen/Dublin arrangements were defunct. The Mediterranean EU members 
were not just hard hit by austerity policies imposed on them after the financial crisis of 2008. Since 2016 they have also become final destinations for the flows of asylumseekers that still use the escape routes across the Mediterranean.

The three main crises we have covered (Table 6.2) presently challenge the states of the Atlantic/Western European areas, and also those of the Nordics. We now turn to the systematic analysis of the new social movements that address these crises.

\subsection{The Anti-Globalization Movement}

(1) The movement against globalization is quite recent, emerging in many countries, especially in the Western world. Organizations such as Attac have mobilized with reference to financial deregulation. A key claim has been for a tax (Tobin tax) on short-term capital movements. Financial deregulation posed a major challenge in the Nordic countries starting in the 1980s (Mjøset, 2011). Deregulation triggered bubbles that burst, with banking crises in Finland, Norway and Sweden as further repercussions in 1991/1992. Denmark had no overt crisis but muddled through a series of near-crisis situations. Sixteen years on, however, all these countries adjusted more easily to the global financial crisis of 2008. For this reason, several commentators paid tribute to 'the Nordic model' - the 'new supermodel', according to The Economist. The one exception was Iceland, which ended up in a dramatic financial meltdown in 2008, gaining a lot of bad publicity - a total contrast to the four others. But in the four large Nordic countries, the financial institutional complex (central bank, regulatory agencies etc.), as well as the banks themselves, had adjusted to shortterm capital movements, drawing on experiences from the 1992 banking crises. Even though the anti-globalization movement demands stronger regulations, it hardly had any significant influence in the Nordic region. Only tiny Iceland, which really was affected, has an active and influential anti-globalization movement.

(2) The regulated internationalism of the Bretton Woods monetary system seems to serve as a benchmark for the anti-globalization movement. It also emphasizes that many features of the new financial sector - such as high wages, bonus mania, irresponsible lending and bubbles in stocks and property - contradict the egalitarian orientation that is embedded in the Nordic institutional complementarities. But even with some rise in income inequalities (especially in Sweden), the Nordic countries still stand as some of the world's most egalitarian economies. Apart from in Iceland, the challenges of 2008 were solved without reaching back to the strongly regulated financial system of the early postwar period.

(3) The anti-globalization movement has supported the critical review of the market paradigm that dominates modern, US-inspired economics, in particular the 'efficient markets hypothesis'. However, the criticism has not had any wide- 
ranging consequences in the Nordic area. The traditional expert networks that have long dominated economic policy-making remain unchallenged. But, again, Iceland deviates. During the escalating economic instabilities of 2006-2008, the government relied on opportunistic and descriptive 'expert' evaluations financed by Iceland's Chamber of Commerce (Mjøset, 2011, pp. 381ff.).

(4) Iceland experienced popular mobilization - the 'pots and pans' revolution against the consequences of the economic meltdown. But unlike in countries such as Greece and Spain, where entirely new parties (Syriza, Podemos) have won victories, Iceland did not see the development of any major new party. Still, its party system is less 'frozen' than those of the other Nordic countries: tensions in Iceland's political system generates new, in most cases short-lasting, parties. They oppose existing parties, which are still not free of clientelist elements that run counter to transparency and credibility. In the spring of 2016, following the Panama papers leaks that showed how a number of Icelandic citizens had fortunes hidden in tax havens, the Pirate Party (founded 2012) gained large support.

(5) Regulatory institutions, in particular the Financial Supervision Authority, have been strengthened in all European countries following the 2008 crisis. This has so far functioned well and has not been dependent on pressure from any social movement. Iceland, however, is a partial exception. While the southern European countries were forced by Brussels and Berlin to pursue austere, deflationary policies, leading to high unemployment (as in Europe during the 1920s), Iceland was outside of EU/Eurozone and had to devalue. It has been claimed that its external devaluation strategy led to a faster recovery (Blyth, 2013). In contrast to the Southern Eurozone countries, Iceland was not forced to pursue internal devaluation (wage deflation). But the taxpayers had to cover enormous expenses incurred as the central bank tried - in vain - to save the banks in October 2008. After the crisis, Iceland has struggled to finance its activities with an inconvertible currency. Many households suffered from expensive indebtedness to the 'rotten banks', and the estates of these banks are now largely owned by hedge funds abroad. Still, Iceland is a very small economy, and when its main resource, fish (cod in particular), is in ample supply and prices are good, the local business cycle will pick up rapidly, as it in fact has over recent years. Presently, there is even a housing boom, partly driven by tourism. Thus, conditions for Iceland's anti-globalization movement have become less favourable. Ahead of the October 2016 election, the Pirate Party did well in the polls, but in the election, the Conservative Independence Party still secured a leading position, forming a government with two smaller splinter parties, The Reform Party and Bright Future.

In sum, the anti-globalization movement has not (with the partial exception of Iceland) led to mobilization that has changed organizational patterns, rules and routines. In the two next areas, however, we find movements that in some respects have influenced such patterns, rules and routines. 


\subsection{The Environmental Movement - An Anti-Waste Movement}

(1) Environmental movements trace their roots back to the early $20^{\text {th }}$ century. Environmentalism was first dominated by movements for the protection of nature, responding to the various ways of using chemicals or dumping industrial waste that would not be fully recycled by local ecosystems.

(2) Many scholars regard indications of global warming as a proof that the world has reached the anthropocene, a geological period defined by the fact that the development of the Earth depends on processes influenced by human beings (McNeill \& Engelke, 2014). Starting in the mid-1980s, a cleavage line developed, pitting groups that articulate interests tied to fossil-based economic activities against groups that pursue green growth strategies based on renewable resources, such as solar energy. The latter groups hold that this green shift will be aided by the extensive knowledge that mankind has achieved through more than 200 years of technological innovation driven by the capitalist quest for profits. These groups take the IPCC forecasts seriously. The former groups believe in technological progress, trusting that a fossil fuel-based capitalism will in itself carry out the necessary adjustments, possibly helped by markets for greenhouse gas emissions.

(3) The environmental protection movement is rooted in the middle class. As indicators of global warming flashed warning signals, the movement could mobilize with reference to ever stronger research findings backed by a broad natural science research community (meteorology depends on physics and chemistry). But such expert consensus does not translate directly into political decisions. The Western world is ridden by a 'psychological climate paradox': the stronger the researchers' warnings, the smaller the share of the population that judge this to be the most important issue on the political agenda (Stoknes, 2015).

(4) Most parties are serious about the risk of a changing climate. Only certain rightwing populist parties openly declare themselves to be 'climate sceptics'. Despite this, the global warming cleavage line has generated separate parties in the Nordic parliamentary systems. They have had varying degrees of success. In three of the countries, green parties have managed to become junior partners in coalition governments: Finland 1995-2003 and 2007-2014, Iceland 2009-13 and Sweden 2014present. In Norway, the Green Party won their first mp in 2013. Only in Denmark (paradoxically the country with the largest share of green exports, such as windmills) has a green party never made it into parliament. Green parties are single-issue parties that demand considerable and immediate reductions in greenhouse gas emissions. As noted, however, global warming is a slow process, playing itself out on a timeline that stretches far into the future, much further than the next election that dominates the horizon of politicians (Brox, 2009). 
(5) Early in the nature conservation period of environmental mobilization, various states organized ministries of natural protection. Since climate policies became a separate policy field, the environmental movement has developed highly professionalized movement organizations that have interacted with authorities and international organizations. All Nordic governments agree to the 'early warning' principle and have launched climate policy measures. Their natural and social scientists contribute to the IPCC, and these scholars are extensively networked into both administrative offices and the movement organizations. This is quite parallel to how the women's movement interacted with administrative offices to frame family policies. In terms of the green shift, however, the strategies of the Nordic countries differed. Since around 1970, Norway developed an industrial structure largely specialized in supplies for oil exploration and extraction. When in 2015 (as in the late 1980s) Saudi Arabia was no longer willing to stabilize the price of oil, Norway was hard hit by the oil price slump. In contrast, the other Nordic countries, in particular Denmark and Sweden, have embarked on a green shift, emphasizing principles of circular economies, adapting their industrial structures and export specialization - at least partly - to the imperatives of a post-fossil age (Kasa, 2016).

\subsection{Resistance against Immigration as a Social Movement}

One final new movement remains to be analyzed. Here, we take our analysis into unchartered waters. We define anti-immigration as a social movement. As Tilly notes, even if social movements flourish under conditions of democracy, they do not necessarily promote democracy. Fascism was a counter-movement to democratic movements in the interwar period. Movements can operate 'on behalf of inequality and exclusion', for instance making claims in favour of expelling recent immigrants (Tilly, 2004c, pp. 181, 185). Our claim is that this has been the most influential new factor in recent Nordic politics. Again, Iceland is the exception.

(1) In the Nordic region, as well as in the rest of Europe, small movements on the extreme right wing formed organizations requiring an immediate, total ban on and even reversal of immigration. Often, these organizations had links back to older fascist and even neo-Nazi traditions. Such attempts have made it impossible to form broader movements against immigration. In the eastern Nordic realm, Sweden and Finland, right-wing parties grew out of fascist traditions, particularly the Sweden Democrats. Finland's True Finns have a more indirect connection through the Rural Party (Landsbygdspartiet), a party that protested against rural poverty, gaining fairly strong support in the early 1970s (Fryklund \& Peterson, 1981). In the western Nordic realm, there were few such connections. Both Denmark and Norway had been occupied by Nazi Germany. In these countries, 'progress parties' emerged as ultra- 
liberal tax-revolt parties in the early 1970s. Only in the 1980s and onwards did they began to benefit politically from growing criticism in regard to immigration.

Movements mostly consist of a core of activists with membershipin a small number of organizations and a larger circle of sympathizers that may not be members but who share the main views of the core activists. But when it comes to anti-immigration mobilization, there are no broad civil society organizations at all. The association to fascism has been too strong. Thus, no basic organizational aims and principles have been formulated. Resistance against immigration only appears via votes for parties that favour strict immigration and integration policies. Furthermore, the movement is strengthened through social media. There is a core network of 'opinion-makers' that reproduce the anti-immigration claims in blogs, websites and commentaries as well as in newspaper/magazine articles and books.

The exception is Iceland. With respect to immigration from non-Western cultures, Iceland's situation is opposite to its situation in the financial field. Iceland has virtually no immigration from non-Western cultures, while the four larger Nordic countries have to tackle the challenge of refugees and asylum-seekers. Iceland has only had EEA-immigration, mainly from Poland. Iceland has a right-wing populist party, but it has never been influential, gaining only 0.2 per cent of the vote in 2016 .

(2) Resistance against immigration is the clearly most important cleavage line to appear in Nordic and European politics through the second period of globalization from the 1970s. The key arguments consist of worries about the consequences of admitting and trying to integrate refugees from non-Western conflict areas. The Nordic countries, it is argued, should rather use their wealth to support refugees and internally displaced people in their native regions.

Possibly, immigration could be a short-term solution to labour supply problems caused by low fertility. But Nordic fertility rates are not as low as elsewhere in Europe. Furthermore, refugees and asylum-seekers are not an entirely functional type of immigrants. If they have escaped from conflict zones, they may likely suffer from various physical or psychological health problems. In any case they bring along cultural frameworks - family forms and religious practices - that appear alien to groups of Nordic natives. Nation-welfare states with a relatively homogenous ethnic population have, so goes the argument, a hard time facing this multiculturalist challenge. Usually, this line of argument considers pull-factors (labour migration) as the dominating motives behind migration flows, ignoring civil war, famine and other conflict zone push-factors.

The immigration-related cleavage line has been politicized independently of dramatic migration peaks. Resistance against immigration is the isolationism of the nation-welfare state. Anti-immigration spokespersons idealize the Nordic models of the golden age of 'embedded liberalism', a time when immigration was at a historical low. Some even refer back to the nation building of the $19^{\text {th }}$ century, when 'national culture' was constructed. Denmark has had the most wide-ranging such discussions. 
Furthermore, anti-immigration arguments refer more or less explicitly to the problem of 'foreign warriors' as proof of how serious the consequences of a liberal immigration regime can be. Sweden is portrayed as the most obvious example of such trends. In extreme formulations, the fear is that the emergence of 'parallel societies' and foreigncultural ghettos will bring conflict zone dynamics to the Nordic part of the world.

(3) The reasoning of immigration critics is mostly at odds with expert knowledge. Demographers either argue that Europe needs immigration (Livi-Bacci, 2012) or that immigration in the long run makes no difference, since immigrants over a few generations will adopt the fertility behaviour of the native population. Other social sciences are less unambiguous. Anthropologists, sociologists and political scientists study identity, integration and networks. Their conclusions cannot be directly translated into positions in politically polarized debates. Critics of immigration often try to discredit such research by claiming that the researchers just internalize the conclusions of the political elites that have been long responsible for overly generous immigration policies. There are significant Nordic differences, with Sweden and Denmark as extremes. In Sweden, the 2015 refugee crisis led to a number of critical voices confronting narrow 'political correctness' in debates on immigration and integration issues. In Denmark, on the other hand, varieties of open scepticism against immigration seem to have become the dominant view.

Criticism against immigration also confronts other movements and institutions at the national level. Immigrants (refugees and particularly asylum-seekers) may themselves be considered a social movement, but their social and political position in the receiving country is very weak. They receive support, however, from a complex of civil society organizations. These are NGOs based on human rights principles as formulated in UN-conventions, often with corporatist ties to the state. Such professional organizations rooted in the majority population contribute practical assistance and also give refugees and asylum-seekers a voice in the public sphere of the receiving country. In addition, waves of asylum-seekers also trigger local, spontaneous and voluntary mobilization, as was seen in 2015.

(4) Since resistance against immigration cannot be organized as separate civil society organizations, the organization of political parties is more important in this area than in other mobilization arenas. Anti-immigration sentiments have spurred electoral support for the new right-wing populist parties since the 1980s, faster in the western than in the eastern regions of Norden. The main demands have been for the strictest possible immigration and integration policies.

Rising support for these parties has brought up the question of participation in coalition governments. In Norway, splits prevailed on the conservative side for a long period. But a modus vivendi was reached when the Progress Party entered a minority coalition government with the Conservatives after the 2013 election. Following Finland's 2015 election, the True Finns were included in a broad majority government 
of three parties (124 out of 200 mandates). In the spring of 2017, the True Finns split, and the splinter party remained in government. In the Danish 2015 election, The Danish People's Party (DPP) emerged as the largest non-socialist party but decided not to join a minority government. Denmark ended up with a non-socialist government on a minority parliamentary basis. DPP supports this government from an autonomous position in parliament. In Sweden, the Sweden Democrats only entered parliament in 2010, doubling their support to $40 \mathrm{mps}$ (out of 349) in the 2014 parliamentary elections. So far the remaining parties have cooperated to isolate the mps of the Sweden Democrats. Given the strong effects of the 2015 refugee crisis in Sweden, it remains an open question as to how long the remaining parties will be able to scale down their own disagreements on other matters to sustain the isolation of the right-wing populists. By 2017, the Swedish Conservative Party seems to have suffered the most from internal ambivalence in this respect.

Any right-wing populist party has local peculiarities. The True Finns is not just critical against non-Western immigrants but also against the Swedish-speaking Finnish minority, who descend from the old elites of the early $19^{\text {th }}$ century. Norway's Progress Party is ambivalent in regard to the country's links with the EU. The DPP in Denmark accepts only inter-state cooperation, explicitly opposing supranational integration. The Finnish and Swedish parties are more unambiguously against EU-membership.

(5) To the extent that right-wing populist parties take part in government coalitions, they experience a dilemma similar to what was earlier felt by left-socialist parties. They must commit to coalition policies that may undermine the support they mobilize from the (unorganized) grass roots. Matching EU routines, each of these countries has established national institutional complexes in the area of immigration and integration (Brochmann \& Hagelund, 2010). These complexes were put to the test during the 2015 refugee crisis. The bracketing of the Schengen/Dublin system blocked escape routes, mainly in Italy and Greece. Norway's Progress Party and Finland's True Finns are both busy administering policies to manage the repercussions of the 2015 refugee crisis in the context of weaker EU supranational capacities. They can push for stricter immigration policies from a position inside the government but also have to join in the celebration of integration policies, to the extent that these are successful. The DPP avoids this problem but then loses out on a number of power positions in bureaucracy, positions that could be used to promote their political programme. In Sweden, the right-wing populist party has thus far not been able to gain any influence in the power apparatus except for the privilege they have in voicing the concerns of the anti-immigration movement in parliamentary debates and hearings.

Although all the Nordic countries tightened their immigration policies, it was the breakdown of the EU immigration regime that solved the problem for them. How long this will last again depends on developments within the EU. 


\subsection{Old and New Movements in the International System}

In section 5, we suggested that Beck's (1986) class/risk society dichotomy can be turned into a distinction between old/offensive and new/defensive movements. Our distinction is defined by the relationship of the movement to (i) mobilization for democracy at the national level, (ii) the level (national/international) at which the cleavage-generating issues arise and (iii) how these issues are experienced (directly or indirectly).

Table 6.3. Main differences between old and new movements

\begin{tabular}{lll}
\hline & \multicolumn{2}{c}{ Movements } \\
\cline { 2 - 3 } & Old/offensive & New/defensive \\
\hline $\begin{array}{l}\text { Role of national-level } \\
\text { democracy in their mobilization } \\
\text { Issue area level }\end{array}$ & Gaining, securing or extending & Precondition \\
$\begin{array}{lll}\text { Perceptions of contested } \\
\text { issues }\end{array}$ & $\begin{array}{l}\text { National } \\
\text { Direct experience at the micro, }\end{array}$ & $\begin{array}{l}\text { Indirect experience via expert } \\
\text { local and national levels }\end{array}$ \\
\hline
\end{tabular}

Table 6.3 summarizes the main differences between the two types. Old movements mobilized with reference to directly experienced issues at the national and lower levels and their gains were always related to democratization at the national level. Risks and/or injustices could be efficiently reduced at the national level.

In contrast, the new/defensive movements (sections 10-12) take democracy at the national level for granted. They direct attention to international risks, specified as three crises of global, international and/or European-wide scope (Table 6.2). Unlike the older ones, they are all 'anti' - against immigration, globalization and waste (greenhouse gases such as $\mathrm{CO}_{2}$ ). They address potential crises from the outside world that threaten the high level of economic development achieved. In the longer run, the new risks may make it harder to sustain the compatibility of capitalism and democracy at the national level.

The old/offensive movements always challenged the reigning state elites with claims that required more democracy and gaining representation and access to government offices, thereby transforming the routine politics of the Nordic states. The new/defensive movements cannot succeed in the same way. The risks they point to are beyond the control of the routine politics of any single national democracy. The reason for contention is not that current routine politics are unable to deal with problems that can be sorted at the national level, but rather that the problems addressed cannot be sorted by any kind of national-level politics, contentious or routine.

For these reasons, the Nordic movements addressing the three contemporary crises are not primarily mobilizing to change national routine politics. To a much larger extent than the old ones, they are eager to work with their nation state 
authorities to exert influence at the international level. Working with the state, they gain access to international organizations, the UN in particular. This is their main chance of influencing the great powers that are the crucial actors in the kind of international coordination needed to deal with risks and/or injustices that emerge in relations between states. Operating in the international field, new movements are guided by democratic norms (autonomy, equality, justice) already established in their Nordic homelands. But as we argued in sections 2 and 5, the international level has no full-fledged state that can be democratized. Instead, there are fluctuations between a sequence of phases - regulated internationalization, globalization and fragmentation (Table 6.1). The new movements are thus forced to relate to hegemony in the international system on the basis of democratic principles already secured at the national level.

The stronger focus on international coordination influences the organizational form of the new social movements. Most of them are 'social movement organizations', relying more on a professional staff (including their own experts) with extensive networks connected to both the authorities and to relevant expert groups in research and higher education than on the classical displays of worthiness, unity, numbers and commitment that features prominently in Tilly's (2004b) definition. They refer more to risks and potential crises forecasted by experts (future effects of global warming, another financial meltdown, fears of immigration undermining the welfare state) than to present-day injustice directly experienced in citizens' daily lives (restrictions on assembly and speech, power exerted at the shop floor or in the family).

Table 6.3 presents a crude dichotomy that is not without exceptions. Certainly, we can find new, contemporary offensive movements, such as the gay or the disability movements. Furthermore, we can also find old, defensive movements. It was briefly noted above that interwar Nordic fascist movements - with their claims for de-democratization - can be seen as a defensive response to a perceived threat to farmers and lower-middle classes by the rising labour movement. Unfortunately, there is no space to pursue such nuances here. We shall stick to the dichotomy and to the selected movements that serve as our cases in this study, convinced that we are on to important differences between the most influential social movements now and before.

We noted (section 3) that social movements make themselves superfluous by successfully taking charge of routine politics. This is largely the case with the old movements in Norden. But at the international level, they still find issues to address. In this respect, they are in the same situation as the new movements: they must work with the democratic state in their country of origin. It can be noted that the classic generation of postwar North-European social democratic leaders were already aware of the increasing importance of the international level. German chancellor Willy Brandt headed a commission on world economic inequalities in 1980, and Sweden's Olof Palme led a similar commission that reported on 'common security' in 1982. 
Norway's Gro Harlem Brundtland headed the already mentioned 'common future' UN report (WCED, 1987) that first brought global warming on the international agenda.

We shall briefly analyze a more recent case. The turn in US support for family planning is an interesting illustration of an international challenge to the Nordic women's movement.

One of the first decisions of the present US Trump administration was to introduce a stricter interpretation of the so-called 'global gag rule' (Mexico City policy), which all US republican presidents have enforced since 1985. The rule requires any NGO that receives US family planning funds to promise that they will not perform or promote abortions anywhere in the world. According to the stricter approach, NGOs that disobey this rule will now not only be blocked from US support to family planning projects explicitly referring to abortion as an option, but they will also lose support for all other kinds of health assistance (HIV, primary care, nutrition, tuberculosis, malaria programmes etc.). The US decision allows savings of as much as USD 8 billion on its present development assistance budget. This imposes a real squeeze on third-world health budgets, since international health NGOs - traditionally drawing much of their financial support from the US - play an important role in poorer countries. One main effect is reduced information to young third-world women about contraception and options for cancelling unwanted pregnancies. Researchers predict that the result will be more pregnancies, more abortions and higher infant mortality. One estimate also has it that the cuts will cause 20000 more women to die every year from complications during pregnancy (The Guardian, 2017).

As noted in section 6, the right to self-determined abortion was an early victory for the women's movements in the Nordic countries. These movements can largely rely on routine politics to defend this right as one element in a Nordic policy package to empower women; however, the consensus is not complete. There are still groups (in fact reaching back to the old religious movements) in national politics that object to this policy and even smaller groups that pursue contentious politics in protest. Also, the relationship to democracy is more complex than in most other issues addressed by the old movements. But the majority in favour is massive.

However, in other countries, for instance in many Latin American countries, rights to abortion are non-existing or highly restricted. Their historical trajectories involved stronger paternalism, reinforced by the Catholic Church. The same is the case in a Baltic country neighbouring Norden, Poland. Following the end of the Cold War, legislation was made much tighter in 1993, and there was again major conflict in 2016 involving a women's strike protesting even stricter proposals (Berer, 2017, p. 21).

In the recent US election, Trump was eager to secure the support of religious conservatives (Davis, 2016, p. 5). Once elected, he was obliged to tighten US family planning support, with the worldwide repercussions surveyed above. Nordic policy responses to the Trump administration's tightening, as reported in the news during the summer of 2017, clearly show the strength of institutionalized 'state feminism'. The Swedish foreign minister for international development promised to support a 
campaign to mobilize the funds lost due to the US policy change, and similar messages were voiced by the Norwegian minister. The two Nordic countries converged, despite governments located on different sides of the political spectrum.

While the inclination to engage at the international level in cooperation with their own democratic state is common to both old and new movements as here defined, the differences specified in Table 6.3 still separate them. The struggle for self-determined abortion had succeeded at the national level. But since no democratic deliberation is possible at the international level, the diplomacy of any nation state will have to respect the integrity of other states. Neither the UN nor any other organization or state can directly intervene to change rules and regulations. Family policy reforms, such as in Latin America or in Poland, can only be achieved through nationally based women's movements (Weitz \& Joffe, 2007). Nordic women's organizations can at the most provide inspiration, information and coordination, supporting diplomatic efforts by the Nordic nation states. In contrast, the issues addressed by the new movements can only be solved by international coordination.

\subsection{Conclusion - The Nordic Models in the 21st Century}

We set out to investigate whether our three new social movements would be as successful as the older ones. Will their response to the three crises (Table 6.2) provide institutions and routines that sustain the institutional complementarities that have benefited the Nordic models thus far?

It is not impossible to imagine an inward turn with further development of complementarities at the national level: a 'fortress nation-welfare state', control of capital movements and a green economy. The first period of globalization developed into a period of fragmentation (1914-1947, Table 6.1) marked by a preference for selfsufficiency. The social partnership institutions of the Nordic labour markets emerged during that inward-oriented period, as noted in section 4. Is it not possible that we will once again experience such an inward turn - this time hopefully without global war?

We have, however, found that the contentious issues at the core of the present three crises differ from earlier ones in that their solutions depend on coordination between large and influential states in the world economy. Thus, presently, new institutional complementarities that result from successful mobilization at the national level are no longer a guarantee against risks in the longer run. Even if the present globalization period will turn into a new situation of fragmentation, the Nordic countries will not be able to benefit from such a development in the same way as they did in the $20^{\text {th }}$ century interwar period. One reason is obviously that they are now among the world's wealthiest economies. They are part of the rich, Western Bloc, and the potential for catching up is less than in that earlier period. But not only that, the features summed up in Table 6.3 also apply. Given that present contentious issues cut across the borders 
between states, they cannot be dealt with by further strengthening democracy at the national level.

More than in the $20^{\text {th }}$ century period of fragmentation, the future of the Nordic models today will depend on circumstances outside of the nation-state borders. While the new movements may be able to influence organizational structures, regulations and routines at the national level, the critical decisions affecting the three problematic issue areas will depend mainly on present and emerging great powers. Both old and new Nordic movements may try to work with their states to have influence at this level, but in the end international coordination between the strongest actors in the international system is needed to counteract problems such as global warming, financial instabilities and flows of forced immigrants across borders into the richer areas of the world. The Nordic models will be more dependent on world state coordination in an age where such coordination seems harder to achieve than in the early postwar period.

Therefore, the successful performance of the Nordic models during the internationalist and globalization phases of US hegemony is no guarantee of continued success during a coming period of fragmentation. A further deepening of national democracy will not be enough. International coordination between the major great powers is required, and that coordination requires international diplomacy involving the hegemonic state and relevant great powers. These negotiations and accords are not guided by the principles of democracy.

The paradox of the present situation is that it needs such international coordination, while in the history of industrial capitalism thus far, the transition from globalization towards fragmentation (Table 6.1) has been associated with a weakening (and even breakdown) of international coordination. Even if the anti-globalization movement, the environmentalists and the critics of immigration got it their way at the Nordic level, the Nordic models would still remain exposed to risks of international financial instability, of new immigration waves through escape routes into the EU/ EEA-region and to climate change resulting from global warming.

\section{References}

Amsden, A. (2004). The Rise of the Rest. New York: Oxford University Press.

Arrighi, G. (1994). The Long Twentieth Century. London: Verso.

Beck, U. (1986). Risikogesellschaft. Frankfurt a.M.: Suhrkamp.

Berer, M. (2017). Abortion Law and Policy Around the World. In Search of Decriminalization. Health and Human Rights, 19(1), 13-27.

Bergqvist, C. et al. (Eds.) (1999). Equal Democracies? Gender and Politics in the Nordic Countries. Oslo: Universitetsforlaget.

Blyth, M. (2013). Austerity. Oxford: Oxford University Press.

Brochmann, G., \& Hagelund, A. (2010). Velferdens grenser. Oslo: Universitetsforlaget.

Brox, O. (2009). Klimakrisen. Hva kan vi gjøre? Oslo: Aschehoug. 
Christiansen, N. F., Petersen, K., Edling, N., \& Haave, P. (Eds.) (2006). The Nordic Model of Welfare. Copenhagen: Museum Tusculanum Press.

Collier, R. B. (1999). Paths Toward Democracy. Cambridge: Cambridge University Press.

Davis, M. (2016). Election 2016. New Left Review, 103(January/February), 5-8.

Eichengreen, B. (2011). Exorbitant Privilege. Oxford: Oxford University Press.

Fryklund, B., \& Peterson, T. (1981). Populism och missnöjespartier i Norden. Lund: Arkiv.

Geddes, A. (2008). Immigration and European Integration. Manchester: Manchester University Press.

Geels, F. (2014). Regime Resistance against Low-carbon Energy Transitions. Theory, Culture \& Society, 31(5), 21-40.

Hernes, H. M. (1987). Welfare State and Woman Power. Oslo: Universitetsforlaget.

Kasa, S. (2016). Klimautfordringer i et norsk og skandinavisk perspektiv. In I. Frønes \& L. Kjølsrød (Eds.), Det norske samfunn (311-334). $7^{\text {th }}$ ed. Oslo: Gyldendal.

Korpi, W. (1981). Labour Movements and Industrial Relations. In E. Allardt et al. (Eds.), Nordic Democracy. Copenhagen: Det Danske Selskab.

Korpi, W. (1983). The Democratic Class Struggle. London: Routledge and Kegal Paul.

Livi-Bacci, M. (2012). A Short History of Migration. Cambridge: Polity.

Maddison, A. (2007). Contours of the World Economy. Oxford: Oxford University Press.

Martin, C. J., \& Swank, D. (2012). The Political Construction of Business Interests. Cambridge: Cambridge University Press.

Massey, D. et al. (1998). Worlds in Motion. Oxford: Clarendon.

McAdam, D., Tarrow, S., \& Tilly, C. (2001). Dynamics of Contention. Cambridge: Cambridge University Press.

McNeill, J. R., \& Engelke, P. (2014). The Great Acceleration. An Environmental History of the Anthropocene since 1945. Cambridge, Mass.: Harvard University Press.

Mjøset, L. (1990). The Turn of Two Centuries. In D. P. Rapkin (Ed.), World Leadership and Hegemony (21-48). Boulder: Lynne Rienner.

Mjøset, L., \& Van Holde, S. (2002). Killing for the State, Dying for the Nation. An Introductory Essay on the Life Cycle of Conscription into Europe's Armed Forces. Comparative Social Research, 20, 3-94.

Mjøset, L. (Ed.) (2011). The Nordic Varieties of Capitalism. Bingley: Emerald.

Mjøset, L. et al. (2012). USA og det utvidede Midtøsten. Vardøger, 33, 120-182.

Mjøset, T. (2016a). Norden - Internasjonale betingelser og sosiale bevegelser. In I. Frønes \& L. Kjølsrød (Eds.), Det norske samfunn (219-244). $7^{\text {th }}$ edition. Oslo: Gyldendal Akademisk,

Mjøset, L. (2016b). The Nordic Route to Development. In J. Ghosh et al. (Eds.), Elgar Handbook of Alternative Theories of Economic Development (533-569). Cheltenham: Edward Elgar.

Mjøset, L., \& Skarstein, R. (2016). Kina gjennom to globaliseringsperioder. Agora, 34(2/3), 85-134. Morel, N. et al. (2012). Towards a Social Investment Welfare State? Bristol: Policy.

Nesser, P. (2015). Islamist Terrorism in Europe. London: Hurst.

Nordhaug, K., \& Skarstein, R. (2012). Kimerika - en levedyktig syntese? Vardøger, 33, 40- 68.

Nielsen, N. K. (2009). Bonde, stat og hjem. Aarhus: Aarhus Universitetsforlag.

Rokkan, S. (1999). State Formation, Nation-Building, and Mass Politics in Europe. Oxford: Oxford University Press.

Rueschemeyer, D., Stephens, E. H., \& Stephens, J. D. (1992). Capitalist Development and Democracy. Cambridge: Polity.

Shefter, M. (1993). Political Parties and the State. Princeton: Princeton University Press.

Stoknes, P. E. (2015). What We Think about When We Try Not to Think about Global Warming. White River: Chelsea Green.

Senghaas, D. (1985). The European Experience. Leamington Spa: Berg. 
Sieferle, R. P. (1990). The Energy System - A Basic Concept of Environmental History. In P. Bribblecombe \& C. Pfister (Eds.), The Silent Countdown (9-20). Berlin: Springer.

Tilly, C. (2004a). Contention and Democracy in Europe, 1650-2000. Cambridge: Cambridge University Press.

Tilly, C. (2004b). Social Movements 1768-2008. Boulder: Paradigm.

Tilly, C. (2004c) Social Movements and Democratisation. In A. -M. Castrén et al. (Eds.), Between Sociology and History (177-193). Helsinki: SKS/Finnish Literature Society.

Tilly, C. (2007). Democracy. Cambridge: Cambridge University Press.

The Guardian (July 11, 2017). Melinda Gates 'deeply troubled' by Donald Trump's planned budget cuts. Retrieved from: https://www.theguardian.com/global- development/2017/jul/11/ melinda-gates-deeply-troubled-by-trump-cuts-to-family- planning-funds [Accessed July 17, 2017].

WCED (World Commission on Environment and Development) (1987). Our common future. Oxford: Oxford University Press.

Weitz, T., \& Joffe, C. (2007). Pro-choice and Pro-life Movements. In G. Ritzer (Ed.), Encyclopedia of Sociology (3651-3656). Oxford: Blackwell. 